\title{
FAKTOR-FAKTOR YANG BERHUBUNGAN TERHADAP PELAKSANAAN IMUNISASI MEASLES RUBELLA
}

\author{
Bella Nuzaini ${ }^{1}$, DewiSayati ${ }^{2}$ \\ ${ }^{1}$ Mahasiswa Prodi Kesmas, STIK Bina Husada Palembang \\ ${ }^{2}$ Dosen Prodi Kesmas Palembang, STIK Bina Husada Palembang \\ Korespondensi Email: atic idkisumsel@yahoo.co.id
}

\begin{abstract}
ABSTRAK
Pendahuluan : Imunisasi Measleas Rubella adalah imunisasi kombinasi untuk mencegah penyakit campak, gondongan, campak Jerman (rubella), dan penyakit yang diberikan oleh virus RNA dari golongan Togavirus. Rubella adalah penyakit virus yang terjadi pada anak dan dewasa muda, gejala ini meliputi demam, batuk, kongjungtivitis, dan ruam kulit. Menurut data cakupan Posyandu Cempaka dan Kenanga yaitu 73,25\%, dengan urutan 9 terbawah dari 41 puskesmas yang sekota Palembang. Metode : Desain penelitian yang digunakan adalah survey analitik dengan pendekatan cross sectional dan teknik pengambilan sampel dengan menggunakan total sampling sebanyak 63 responden, yang selanjutnya dilakukan uji statistik chi-square, dengan derajat kepercayaan 95\%. Hasil : hasil uji statistik menunjukkan bahwa ada hubungan antara pengetahuan ( $p$ value 0,003$)$, sikap ( $p$ value 0,002$)$, dukungan keluarga ( $p$ value 0,001$)$, peran petugas ( $p$ value 0,007 ) dengan pelaksanaan imunisasi Measleas Rubella, dan tidak ada hubungan antara jarak tempuh ( $p$ value 0,092 ), dan peran tokoh masyarakat ( $p$ value 0,101 ) dengan pelaksanaan imunisasi Measleas Rubella. Kesimpulan : pengetahuan, sikap, dukungan keluarga, peran petugas menjadi faktor berhubungan dengan pelaksanaan imunisasi Measleas Rubella
\end{abstract}

Kata Kunci : Imunisasi, Measleas Rubella

\section{Related Factors on Implementing Immunization of Measles Rubella}

\begin{abstract}
Introductions : Measleas Rubella immunization is a combination immunization to prevent measles, mumps, German measles (rubella), and diseases given by the RNA virus from the Togavirus class. Rubella is a viral disease that occurs in children and young adults. Symptoms include fever, cough, conjunctivitis and skin rash. According to data, the coverage of PosyanduCempaka and Kenanga is $73.25 \%$, with the lowest 9 out of 41 health centers in Palembang. Methods: The research design used was an analytic survey with a cross sectional approach and a sampling technique using a total sampling of 63 respondents, which was then performed a chi-square statistical test, with a confidence degree of $95 \%$. Results: the results of statistical tests showed that there was a relationship between knowledge ( $p$ value 0.003), attitude ( $p$ value 0.002$)$, family support ( $p$ value 0.001 ), the role of officers ( $p$ value 0.007 ) with the implementation of Measleas Rubella immunization, and there was no relationship between distance exposure ( $p$ value 0.092), and the role of community leaders ( $p$ value 0.101 ) with the implementation of Measleas Rubella immunization. Conclusion: knowledge, attitude, family support, and the role of officers are factors related to the implementation of measles rubella immunization.
\end{abstract}

Keywords : Immunization, Measles Rubella

\section{PENDAHULUAN}

Imunisasi Measles Rubella adalah imunisasi kombinasi untuk mencegah penyakit campak, gondongan, campakJerman (Rubella) dan penyakit yang disebabkan oleh virus RNA dari golongan togavirus (Cahyono, 2010).
Rubella adalah penyakit yang umumnya terjadi pada anak dan dewasa muda, yang ditandai oleh prodromal yang pendek, pembesaran kelenjar getah bening servikal, suboksi pital dan postaurikular, disertai erupsi yang berlangsung 2-3 hari dan dapat terjadi insfeksi berat seperti 
kelainan sendi dan purpura (Nuraif\& Kusuma, 2016)

Menurut WHO (2015), penyakit campak merupakan salah satu penyakit menular yang masih menjadi masalah kesehatan bayi dan anak. Pada tahun 2013, di dunia terdapat 145.700 orang meninggal dunia akibat campak, sedangkan sekitar 400 kematian setiap hari sebagian besar terjadi pada balita (Ramadhani, 2016).

Dalam Global Vaccine Action Plan (GVAP), campak dan rubella ditargetkan untuk dapat dieliminasi di 5 regional WHO pada tahun 2020. Sejalan dengan GNAP, The Global Measles \& Rubella Strategic Plan 2012-2020 memetakan strategi yang diperlukan untuk mencapai target dunia tanpa campak, rubella atau CRS. Satu diantara lima strategi adalah mencapai dan mempertahankan tingkat kekebalan masyarakat yang tinggi dengan memberikan dua dosis vaksin yang mengandung campak dan rubella melalui imunisasi rutin dan tambahan dengan cakupan tinggi (>95\%) dan merata (Pramitasari, 2017).

Di Indonesia pada tahun 2016 terdapat 5.502 kasus campak, angka ini mengalami penurunan pada tahun 2017 sebanyak 3.143 kasus. Sedangkan awal tahun 2018, kejadian luar biasa di Asmat Papua menelan 79 korban jiwa dari total 700 kasus yang dilaporkan (Kemenkes RI, 2018).

Berdasarkan Profil Kesehatan Indonesia, cakupan imunisasi lanjutan pada baduta di Indonesia dengan jumlah $62,2 \%$, tetapi masih banyak propinsi yang belum memenuhi target yang diharapkan diantaranya Aceh $(20,4)$, Papua $(26,6 \%)$, NTT (34\%), Riau (34,8\%), dan Kalimantan Utara (35,3\%), (Kemenkes RI, 2018)

Berdasarkan Profil Kesehatan Sumatera Selatan Tahun 2015, bahwa status imunisasi penderita positif rubella mempunyai gejala yang mirip dengan campak terdapat pada kelompok umur $<5$ tahunya itu sebesar 16.

Guna menekan angka kesakitan dan kematian serta melengkapi imunisasi dasar lengkap, maka mulai tahun 2017 pemerintah menambahkan vaksin baru yaitu Measles Rubella (MR), menggantikan vaksin campak yang selama ini dipakai (Kemenkes Rl, 2017).

Berdasarkan data Dinas Kesehatan Kota Palembang bahwa target imunisasi Measles Rubella adalah sebesar $\geq 90 \%$ (Dinkes Kota Palembang, 2017).

Berdasarkan data Puskesmas Tegal Binangun Palembang menunjukkan bahwa cakupan imunisasi Measles Rubella adalah sebesar $84,8 \%$ dengan urutan ke 9 terbawah dari 41 Puskesmas yang ada di Kota Palembang. Sedangkan cakupan imunisasi Measles Rubella pada wilayah kerja Puskesmas Tegal Binangun Palembang yaitu Posyandu Cempaka 85,92\% dan Posyandu Kenanga 73,25\% (Puskesmas Tegal Binangun Palembang, 2017).

Terdapat beberapa faktor yang mempengaruhi dalam pelaksanaan imunisasi measles rubella ini antara lain pengetahuan, sikap, jarak tempuh, dukungan keluarga, peran petugas dan peran tokoh masyarakat. Berdasarkan survey pendahuluan yang dilakukan peneliti bahwa dari 10 responden, terdapat 3 responden yang menolak anaknya untuk di imunisasi measles rubella. Hal ini disebabkan oleh kurangnya dukungan keluarga dan memiliki sikap negatif terhadap imunisasi measles rubella, yaitu terjadi hal-hal yang tidak diinginkan setelah memperoleh imunisasi tersebut. Seperti contoh anaknya akan mengalami kecacatan atau lumpuh.

Berdasarkan data diatas, maka peneiti tertarik melakukan penelitian tentang Faktor-faktor Yang Berhubungan Terhadap Pelaksanaan Imunisasi Measles Rubella Tahun 2019.

\section{BAHAN DAN METODE}

Desain penelitian adalah survey analitik kuantitatif dengan pendekatan cross sectional. Penelitian dilaksanakan pada tanggal 25-31 Mei 2019.

Sampel dalam penelitian ini adalah ibuibu yang membawa balita berkunjung untuk memperoleh pelayanan kesehatan di posyandu wilayah kerja puskesmas Tegal Binangun yang berjumlah sebanyak 63 responden, pengambilan sampel dengan menggunakan teknik Total Sampling. Pengumpulan data primer dilakukan 
melalui wawancara langsung dengan mengunakan kuesioner. Data sekunder diperoleh dari dokumen yang ada di puskesmas. Pengolahan data dilakukan mulai dari pengeditan data, pengolahan, tabulasi, entry data, dan pembersihan data. Serta analisis data dengan teknik analisis univariat dan bivariat dengan menggunakan uji statistik Chi-Square.
HASIL

\section{Univariat}

Berdasarkan tabel 1 diatas, diketahui bahwa dari 63 responden, responden yang menyatakan posyandu melaksanakan imunisasi measles rubella sebanyak 36 responden $(57,1 \%)$, lebih banyak dibandingkan dengan responden yang menyatakan bahwa posyandu tidak melaksanakan imunisasi measles rubella sebanyak 27 responden (42,9\%), responden yang memiliki pengetahuan baik sebanyak 18 responden $(28,6 \%)$ lebih sedikit dibandingkan dari responden yang memiliki pengetahuan kurang sebanyak 45

Tabel 1

Distrubisi Frekuensi Pelaksanaan Imunisasi Measles Rubella, Pengetahuan Ibu, Sikap Ibu, Jarak Tempuh, Dukungan Keluarga, Peran Petugas Kesehatan, dan Peran Tokoh Masyarakat Variabel Frekuensi (f) Presentase (\%)

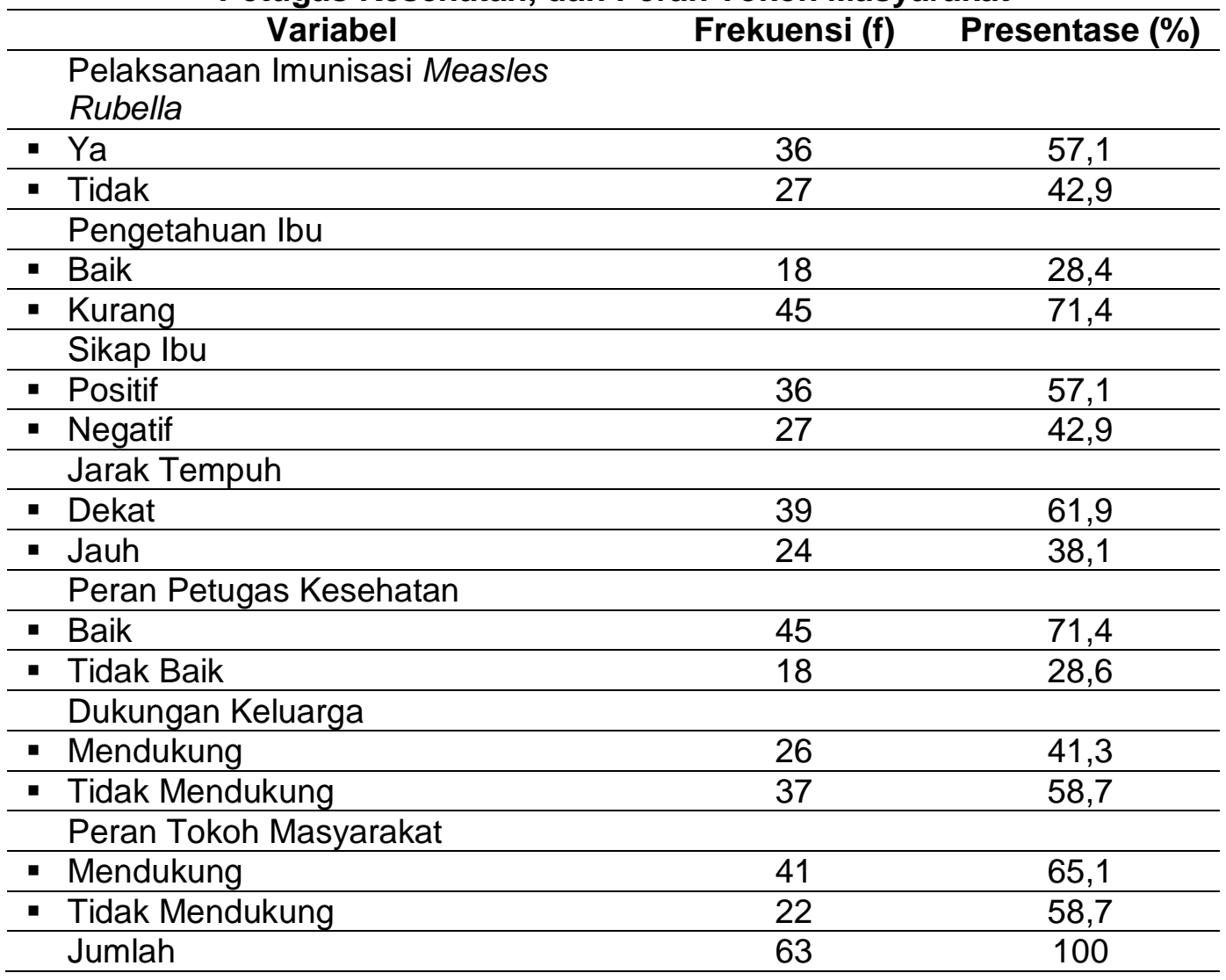

responden $(71,4 \%)$, responden yang memiliki sikap positif sebanyak 36 responden $(57,1 \%)$, lebih banyak dibandingkan responden yang sikap negative sebanyak 27 responden $(42,9 \%)$, responden yang menyatakan jarak tempuh dekat sebanyak 39 responden $(61,9 \%)$, lebih banyak dibandingkan responden yang menyatakan jarak tempuh jauh sebanyak 24 responden (38,1\%), responden yang menyatakan peran petugas kesehatan baik sebanyak 45 responden $(71,4 \%)$ lebih banyak dibandingkan dari responden yang 
menyatakan peran petugas kesehatan tidak baik sebanyak 18 responden $(28,6 \%)$, responden yang menyatakan keluarga mendukung sebanyak 26 responden $(41,3 \%)$, lebih sedikit dibandingkan responden yang menyatakan keluarga tidak mendukung sebanyak 37 responden $(58,7 \%)$, responden yang menyatakan tokoh masyarakat yang mendukung pelaksanaan imunisasi measles rubella sebanyak 41 responden $(65,1 \%)$ lebih banyak dibandingkan dari responden yang menyatakan tokoh masyarakat yang tidak mendukung pelaksanaan imunisasi measles rubella sebanyak 22 responden $(34,9)$.

\section{Bivariat}

Berdasarkan hasil penelitian pada analisa bivariat diketahuinya hubungan antara Pengetahuan Ibu, Sikap Ibu, Jarak Tempuh, Peran Petugas Kesehatan, Dukungan Keluarga, dan Peran Tokoh Masyarakat terhadap Pelaksanaan Imunisasi Maesles Rubella, dapat dilihat pada tabel sebagai berikut :

Tabel 2.

Hubungan antara Pengetahuan Ibu, Sikap Ibu, Jarak Tempuh, Peran Petugas Kesehatan, Dukungan Keluarga, dan Peran Tokoh Masyarakat terhadap Pelaksanaan Imunisasi Me

\begin{tabular}{|c|c|c|c|c|c|c|c|}
\hline \multirow{4}{*}{ Variabel } & \multirow{2}{*}{\multicolumn{4}{|c|}{$\begin{array}{c}\text { Pelaksanaan Imunisasi } \\
\text { MR }\end{array}$}} & \multirow{3}{*}{\multicolumn{2}{|c|}{ Jumlah }} & \multirow{4}{*}{ P-Value } \\
\hline & & & & & & & \\
\hline & \multicolumn{2}{|l|}{ Ya } & \multicolumn{2}{|c|}{ Tidak } & & & \\
\hline & $\mathbf{N}$ & $\%$ & $\mathbf{N}$ & $\%$ & $\mathbf{n}$ & $\%$ & \\
\hline Pengetahuan lbu & & & & & & & \multirow{3}{*}{0,003} \\
\hline - Baik & 16 & 88,9 & 2 & 11,1 & 18 & 100 & \\
\hline - Kurang & 20 & 44,4 & 25 & 55,6 & 45 & 100 & \\
\hline \multicolumn{7}{|l|}{ Sikap lbu } & \multirow{3}{*}{0,002} \\
\hline - Positif & 27 & 75,0 & 9 & 25,0 & 36 & 100 & \\
\hline - Negatif & 9 & 33,3 & 18 & 66,7 & 27 & 100 & \\
\hline \multicolumn{7}{|l|}{ Jarak Tempuh } & \multirow{3}{*}{0,092} \\
\hline - Dekat & 26 & 66,7 & 13 & 33,3 & 39 & 100 & \\
\hline - Jauh & 10 & 41,7 & 14 & 58,3 & 24 & 100 & \\
\hline \multicolumn{7}{|l|}{ Dukungan Keluarga } & \\
\hline - Mendukung & 8 & 30,8 & 18 & 69,2 & 26 & 100 & \\
\hline - Tidak Mendukung & 28 & 75,5 & 9 & 24,3 & 37 & 100 & \\
\hline \multicolumn{7}{|l|}{ Peran Nakes } & \\
\hline - Baik & 31 & 68,9 & 14 & 31,1 & 45 & 100 & \\
\hline - Tidak Baik & 5 & 27,8 & 13 & 72,2 & 18 & 100 & \\
\hline \multicolumn{7}{|c|}{ Peran Tokoh Masyarakat } & \\
\hline - Mendukung & 27 & 65,9 & 14 & 34,3 & 41 & 100 & \\
\hline - Tidak Mendukung & 9 & 40,9 & 13 & 59,1 & 22 & 100 & \\
\hline Jumlah & 36 & 57,1 & 27 & 42,9 & 63 & 100 & \\
\hline
\end{tabular}

Berdasarkan tabel 2 didapatkan hasil bahwa responden yang menyatakan pengetahuan ibu baik dan melaksanakan imunisasi MR sebanyak 16 responden $(88,9 \%)$, lebih banyak dibandingkan responden yang menyatakan pengetahuan ibu baik tetapi tidak melaksanakan imunisasi MR sebanyak 2 responden $(11,1 \%)$ dan hasil uji statistic dengan menggunakan chi-square didapatkan pvalue $(0,003)$, yang berarti ada hubungan yang signifikan antara pengetahuan ibu terhadap pelaksanaan imunisasi MR. Responden yang memiliki Sikap positif dan melaksanakan imunisasi MR sebanyak 27 responden $(75 \%)$, lebih banyak dibandingkan responden yang memiliki sikap positif tetapi tidak melaksanakan imunisasi MR sebanyak 9 responden $(25 \%)$ dan hasil uji statistik dengan 
menggunakan chi-square didapatkan $p$ value $(0,002)$, yang berarti ada hubungan yang signifikan antara sikap ibu terhadap pelaksanaan imunisasi MR. Responden yang menyatakan Jarak tempuh dekat dan melaksanakan imunisasi MR sebanyak 26 responden $(66,7 \%)$, lebih banyak dibandingkan responden yang menyatakan jarak tempuh dekat tetapi tidak melaksanakan imunisasi MR sebanyak 13 responden $(33,3 \%)$ dan hasil uji statistik dengan menggunakan chi-square didapatkan $p$ value $(0,092)$, yang berarti tidak ada hubungan yang signifikan antara jarak empuh terhadap pelaksanaan imunisasi MR. Responden yang mendapat dukungan keluarga dan melaksanakan imunisasi MR sebanyak 8 responden $(30,8 \%)$, lebih sedikit dibandingkan responden yang mendapat dukungan keluarga tetapi tidak melaksanakan imunisasi MR sebanyak 18 responden $(69,2 \%)$ dan hasil uji statistik dengan menggunakan chi-square didapatkan $p$ value $(0,001)$, yang berarti ada hubungan yang signifikan antara dukungan keluarga terhadap pelaksanaan imunisasi MR. Responden yang menilai peran petugas kesehatan baik dan melaksanakan imunisasi MR sebanyak 31 responden $(68,9 \%)$, lebih banyak dibandingkan responden yang menilai peran petugas baik tetapi tidak melaksanakan imunisasi MR sebanyak14responden $(31,1 \%)$ dan hasil uji statistik dengan menggunakan chisquare didapatkan $p$ value $(0,007)$, yang berarti ada hubungan yang signifikan antara peran petugas kesehatan terhadap pelaksanaan imunisasi MR. Responden yang menyatakan peran tokoh masyarakat mendukung dan melaksanakan imunisasi MR sebanyak 27 responden (65,9\%), lebih banyak dibandingkan responden yang menyatakan peran tokoh masyarakat mendukung tetapi tidak melaksanakan imunisasi MR sebanyak 14 responden $(34,1 \%)$ dan hasil uji statistik dengan menggunakan chi-square didapatkan $p$ value $(0,101)$, yang berarti tidak ada hubungan yang signifikan antara peran tokoh masyarakat terhadap pelaksanaan imunisasi MR.

\section{PEMBAHASAN \\ Hubungan Pengetahuan Ibu Terhadap Pelaksaaan Imunisasi MR}

Berdasarkan hasil uji bivariat menunjukkan bahwa terdapat hubungan yang signifikan antara pengetahuan ibu terhadap pelaksanaan imunisasi MR. Pengetahuan adalah hasil tahu seseorang terhadap objek melalui indera yang dimiliki (mata, hidung, telinga, dan sebagainya), atau hasil penginderaan manusia. Pengetahuan yang dihasilkan tersebut dipengaruhi oleh lamanya intensitas perhatian dan persepsi terhadap objek (Notoadmodjo, 2010).

Menurut Kemenkes RI (2017) vaksin Measles Rubella (MR) diberikan guna mencegah terjadinya penyakit yang disebabkan oleh virus campak (measles) dan campak jerman (rubella). Dengan adanya pemberian imunisasi measles dan rubella bisa melindungi anak dari kecacatan dan kematian yang diakibatkan oleh pneumonia, diare, kerusakan otak, ketulian, kebutaan serta penyakit jantung bawaan.

Pengetahuan akan menjadi motivasi seseorang untuk melakukan tindakan. Tindakan yang didasari oleh pengetahuan akan lebih konsisten atau menetap dibandingkan tindakan tanpa didasari pengetahuan (Sari, 2018).

Hasil penelitian ini sejalan dengan Marlinta dan Candrasari Anika (2018) tentang hubungan pengetahuan ibu tentang vaksin MR pada balita di Puskesmas Kotagede I Yogyakarta, dengan nilaip value $(0,006)$.

Berdasarkan hasil penelitian, teori, dan penelitian terkait, maka peneliti berasumsi bahwa sebagian besar pengetahuan ibu sudah baik, walaupun masih terdapat pengetahuan ibu kurang. Semakin baik pengetahuan seseorang, maka semakin besar kemungkinan untuk melaksanakan. Imunisasi Measles Rubella, karena pengetahuan akan menjadi motivasi seseorang melaksanakan imunsasi Measles Rubella, sehingga target yang telah ditetapkan, bisa tercapai sesuai keinginan. 


\section{Hubungan Sikap Ibu Terhadap Pelaksanaan Imunisasi Measles Rubella.}

Berdasarkan hasil bivariat menunjukkan bahwa ada hubungan yang signifikan antara sikap ibu terhadap pelaksanaan imunisasi MR. Sikap adalah respon seseorang yang masih tertutup terhadap suatu stimulus atau object tertentu, yang melibatkan faktor pendapat dan emosi yang bersangkutan (senangtidak senang, setuju-tidak setuju, baik-tidak baik, dan sebagainya). (Notoadmodjo, 2012).

Hasil penelitian ini sejalan dengan penelitian Primitasari (2017) mengenai "Hubungan Sikap Dengan Kepatuhan dalam mengikuti imunisasi (Measles Rubella) MR, dengan hasil uji statistik yang diperoleh nilai $p$ value $(0,027)$.

Berdasarkan hasil penelitian, teori, dan penelitian terkait, maka peneliti berasumsi bahwa sebagian besar ibu-ibu memiliki sikap positif, walaupun masih ada bersikap negatif. Ibu-ibu yang memiliki sikap positif cenderung lebih memilih anaknya diberikan imunisasi measles rubella demi kesehatan anaknya. Sedangkan ibu-ibu yang mempunyai sikap negative cenderung tidak akan memilih memberikan anaknya imunisasi measles rubella karena terdapat beberapa faktor yang mempengaruhi sikap negatifnya antara lain pengalaman pribadi, pengaruh orang lain yang dianggap penting, dan pengaruh budaya. Pendidikan dan pengetahuan memberikan pengaruh besar terhadap pembentukan sikap seseorang.

\section{Hubungan Jarak Tempuh Terhadap Pelaksanaan Imunisasi Measles Rubella.}

Berdasarkan hasil bivariat diperoleh hasil bahwa tidak ada hubungan yang signifikan antara jarak tempuh terhadap pelaksanaan imunisasi MR. Jarak adalah ruang atau sela yang menghubungkan antara dua lokasi atau dua objek dan dihitung melalui hitungan panjang maupun waktu. Jarak memiliki peranan penting dalam kehidupan sosial, ekonomi, dan politik. Jarak menjadi salah satu faktor yang mempengaruhi mina tibu-ibu untuk membawa balitanya ke posyandu untuk memperoleh pelayanan kesehatan. Banyak pertimbangan untuk mengunjungi posyandu karena jarak (Andryana, 2015).

Hasil penelitian ini sejalan dengan hasil penelitian Andyana, 2015, yaitu mengenai faktor yang mempengaruhi minat ibu-ibu mengunjungi posyandu, dengan hasil yang diperoleh sebesar 67,7\% ibu-ibu yang memiliki jarak tempuh dekat dari posyandu cenderung rutin berkunjung.

Berdasarkan hasil penelitian, teori, dan penelitian terkait, maka peneliti berasumsi bahwa mayoritas ibu-ibu memiliki jarak tempuh dekat dengan posyandu sehingga mau melaksanakan imunisasi measles rubella, walaupun masih ada ibu-ibu yang memiliki jarak tempuh dekat tidak melaksanakan imunisasi measles rubella. Namun terdapat juga ibu-ibu yang memiliki jarak tempuh jauh masih mau ke posyandu dan melaksanakan imunisasi measles rubella. Didapatkan informasi bahwa lbuibu yang tidak mau melaksanakan imunisasi measles rubella memiliki alasan yaitu mereka beranggapan bahwa imunisasi measles rubella tidak terlalu penting bagi balita atau anaknnya walaupun jarak yang ditempuh dekat maupun jauh.

\section{Hubungan Dukungan Keluarga terhadap Pelaksanaan Imunisasi Measles Rubella}

Berdasarkan hasil bivariat diperoleh bahwa ada hubungan yang signifikan antara dukungan keluarga terhadap pelaksanaan imunisasi MR. Dukungan keluarga adalah sebuah proses yang terjadi sepanjang masa kehidupan. Sifat dan jenis dukungan berbeda dalam berbagai ahap-tahap siklus kehidupan. Dukungan keluarga dapat berupa dukungan sosial internal, seperti dukungan suami, istri atau dukungan dari saudara kandung dan dapat juga berupa dukungan eksternal bagi keluarga inti. Sebagai akibatnya, hal ini meningkatkan kesehatan dan adaptasi keluarga (Friedman, 2010).

Hasil penelitian ini sejalan dengan penelitian Sari (2018), mengenai hubungan antara dukungan keluarga ibu terhadap imunisasi dengan pemberian imunisasi dasar bayi di walayah kerja Puskesmas Korpri Kecamatan Sukarame Kota Bandar Lampung, dengan pvalue $(0,004)$. 
Berdasarkan hasil penelitian, teori, dan penelitian terkait, maka peneliti berasumsi bahwa sebagian besar ibu-ibu tidak mendapatkan dukungan keluarga dalam pelaksanaan imunisasi measles rubella dikarenakan keluarg masih mempercayai bahwa vaksin yang digunakan haram.

\section{Hubungan Peran Petugas Kesehatan terhadap Pelaksanaan Imunisasi Measles Rubella}

Berdasarkan hasil bivariat diperoleh hasil bahwa ada hubungan yang signifikan antara peran petugas kesehatan terhadap pelaksanaan imunisasi MR. Hasil penelitian ini sejalan dengan penelitian Tiani, dkk (2016), tentang "Peran Petugas Imunisasi dalam Pemberian Vaksinasi Pentavalen", dengan $p$ value $(0,013)$.

Berdasarkan hasil penelitian, teori, dan penelitian terkait, maka peneliti berasumsi bahwa mayoritas ibu-ibu menilai peran petugas kesehatan baik, walaupun masih ada peran petugas yang tidak baik dalam pelaksanaan imunisasi measles rubella. Hal ini dikarenakan masih kurangnya penyuluhan tentang imunisasi measles rubella di wilayah tersebut.

\section{Hubungan Peran Tokoh Mayarakat terhadap Pelaksanaan Imunisasi Measles Rubella}

Berdasarkan hasi analisis yang telah dilakukan didapatkan hasil bahwa tidak ada hubungan yang signifikan antara peran tokoh masyarakat terhadap pelaksanaan imunisasi MR. Upaya pergerakan masyarakat dilakukan melalui strategi komunikasi interpersonal yang baik. Tujuan kegiatan mobilisasi masyarakat ini adalah agar masyarakat sadar dan mau membawa anaknya yang berusia 9 bulan sampai<15 tahun ke pos pelayanan imunisasi selama masa kampanye untuk mendapatkan imunisasi MR (Ditjen P2P, 2017).

Sasaran mobilisasi masyarakat dalam rangka kampanye imunisasi MR adalah para orang tua, sekolah-sekolah, kelompok-kelompok sosial kemasyarakatan, tokoh masyarakat, tokoh agama, dan LSM-LSM setempat. Petugas kesehatan di setiap tingkatan administrasi bertanggungjawab dalam memantau proses mobilisasi ini berjalan sesuai yang diharapkan (MUI, 2016). Hasil penelitian ini sejalan dengan penelitian Munawaroh, dkk (2016), mengenai "Beberapa Faktor Yang Berhubungan Praktik Imunisasi Pentavalen Booster di wilayah Puskesmas Mangunsarisalatiga, dengan pvalue $(0,104)$.

Berdasarkan hasil penelitian, teori, dan penelitian terkait, maka peneliti berasumsi bahwa sebagian besar tokoh masyarakat mendukung dalam pelaksanaan imunisasi Measles Rubella. Walaupun masih ada tokoh masyarakat yang tidak mendukung. $\mathrm{Hal}$ ini berpengaruh besar dalam mengubah perilaku masyarakat yang ada di wilayah kerja Puskesmas Tegal Binangun.

\section{SIMPULAN DAN SARAN Simpulan}

Berdasarkan hasil penelitian yang telah dilakukan, maka diperoleh hasil ada hubungan yang signifikan antara pengetahuan ibu, dukungan keluarga, peran petugas kesehatan dengan pelaksanaan imunisasi MR, namun tidak ada hubungan yang signifikan antara peran tokoh masyarakat terhadap pelaksanaan imunisasi MR.

\section{Saran}

Diharapkan Puskesmas Tegal Binangun, dapat memberikan penyuluhan secara rutin dan berkala tentang imunisasi Measles Rubella di Wilayah Kerja Puskesmas Tegal Binangun. Pendekatan kepada keluarga, kerabat dekat, dan para warga agar keluarga lebih memberikan dukungan terhadap pelaksanaan imunisasi Measles Rubella juga perlu dilakukan, karena dukungan keluarga sangat penting dalam mendukung keberhasilan pelaksanaan imunisasi Measles Rubella. Peran tokoh masyarakat juga perlu ditingkatkan untuk ikut serta dalam membantu mensosialisasikan pelaksanaan imunisasi Measles Rubella di Wilayah Kerja Puskesmas Tegal Binangun Tahun 2019, supaya masyarakat percaya dan tidak perlu merasa takut melaksanakan imunisasi Measles Rubella. 


\section{KONFLIK KEPENTINGAN}

Tidak ada potensi konflik kepentingan yang dilaporkan oleh penulis.

\section{KEPUSTAKAAN}

Adryana Ria, 2015. Minat Ibu Mengunjungi Posyandu Di Wilayah Kerja Puskesmas Simpang BaruKecamatanTampan. E-Jurnal, Vol. 2, No. 2, Oktober 2015. Universitas Riau-FISIP, Pekanbaru. (Online) https://jom.unri.ac.id/index.php/ JOMFSIP/article/view/7419.

Cahyono Suharjo, dkk., 2010. Vaksinasi Cara Ampuh Cegah Penyakit Infeksi. Yogyakarta : Kanisius.

Dinas Kesehatan Propinsi Sumatera Selatan, 2015. Profil Kesehatan Propinsi Sumatera Selatan.

Dinas Kesehatan Kota Palembang, 2018. Profil Kesehatan Kota Palembang Tahun 2017.

Ditjen P2P, 2017. Laporan Kinerja Direktorat Jenderal Pencegahan dan Pengendalian Penyakit. Jakarta : Kemenkes Republik Indonesia

Friedmen MM, 2010. Buku Ajar Keperawatan : Riset, Teori, Dan Praktek. Jakarta : EGC.

Kemenkes RI, 2018.Profil Kesehatan Indonesia Tahun 2017.

Kemenkes RI, 2017. Cakupan Imunisasi MR Tahap 1 Lampaui Target. Jakarta. Diakses tanggal 13 September 2020. (Online).

http://www.depkes.go.id/pdf.php?id=1 7100300002.

MUI, 2016. Majelis Ulama Indonesia Propinsi Sumatera Selatan Tentang Imunisasi Vaksin MR.

Munawaroh Anisah, dkk., 2016. Beberapa Faktor Yang Berhubungan Dengan Praktik Imunisasi Pentavalen Booster Di Wilayah Kerja Puskesmas
Mangunsari Salatiga. E-Jurnal. Vol. 4, No. 3, Juli 2016 (ISSN : 2356-3346). Online.

http://ejournal-

s1.undip.ac.id/index.php/jkm

Notoadmodjo Soekidjo, 2012. Metodologi Penelitian Kesehatan. Penerbit : Rineka Cipta, Jakarta.

Notoadmodjo Soekidjo, 2010. Metodologi Penelitian Kesehatan. Penerbit : RinekaCipta, Jakarta.

Nuraif Amir Huda dan Kusuma Hardhi, 2016. Asuhan Keperawatan Praktis. Penerbit : Mediaction Jogya, Yogyakarta.

Pramitasari Dwi Ayu dan Ian Rossalia Pradita Putri, 2017. Hubungan Pengetahuan dan Sikap lbu Dengan Kepatuhan Dalam Mengikutilmunisasi MR Massal Di Posyandu Wilayah Kerja Puskesmas Nganglik II Kabupaten Sleman Yogyakarta Tahun 2017. E-Jurnal. Universitas Yogyakarta, Yogyakarta.

Available : file://C:/Users/win7/ Downloads/98-129-1-PB.pdf.

Ramadhani Nuri Fatimah, 2016. Hubungan Status Imunisasi Dan Riwayat Kontak Dengan Kejadian Campak Pada Balita Di Kabupaten Sukoharjo. Skripsi. Universitas Muhammadiyah Surakarta. Online http://eprints.ums.ac.id/47105/1/2.\%2 ONASKAH\%20PUBLIKASI\%20\%20.p df.

Sari Desti Diana, 2018. Faktor-faktor Pada Ibu Yang Berhubungan Dengan Pemberian Imunisasi Dasar Bayi Di Wilayah Kerja Puskesmas Korpri Kecamatan Sukarame Kota Bandar Lampung. Skripsi. Online. http://digilib.unila.ac.id/30116/3/SKRIP SI\%20TANPA\%20BAB\% 20PEMBAHASAN.pdf. 